\title{
E-Governance Initiatives in Maharashtra (India): Problems and Challenges
}

\author{
Laxman L. Kumarwad \\ Government College of Engineering, Karad, 415124, India \\ Email: laxmankumarwad@gmail.com \\ Rajendra D. Kumbhar \\ KBP Institute of Management Studies and Research, Satara, 415015, India \\ Email: rdk14@rediffmail.com
}

\begin{abstract}
In this digital world, research interest is being increased on e-governance, existing research isn't adequately address key issues regarding the development, implementation and integration of the e-governance projects. The delivering of e-services to the citizens at their door is the primary function of government. The Maharashtra state is the pioneer in citizen centric egovernance initiatives like Common Service Centre (Maha e-Seva, SETU), Public Distribution System (PDS), Land Record (Bhoomi Abhilekh) etc. The present research is efforts to identify and establish linkages between the factors responsible for creating a suitable environment for effective implementation of egovernance services in government offices. The objective of the present research paper is to establish the background for the development of a conceptual framework of e-governance initiatives. Based on the existing literature review the paper provides an analysis of existing empirical findings and conceptual perspectives related to e-governance initiatives in Satara District, Maharashtra, India.
\end{abstract}

Index Terms-E-Governance, ICT, CSC, Public Distribution System, Land Record.

\section{INTRODUCTION}

Electronic Governance or E-Governance is primarily related to executing the functions and achieving the results of governance using Information and Communications Technology (ICT). UNESCO defines "E-Governance is the use of ICT by different actors of the society with the aim to improve their access to information and to build their capacities" [1]. Dr. A. P. J. Abdul Kalam, former President of India, visualized eGovernance as "A transparent smart e-Governance with seamless access, secure and authentic flow of information crossing the interdepartmental barrier and providing a fair and unbiased service to the citizen" [2]. International Institute for Communication and Development (IICD) defined e-governance as "the application of electronic means in: (1) the interaction between the government and citizens and government and businesses, as well as (2) in internal government operations to simplify and improve democratic, government and business aspects of governance" [3]. E-Governance is the use of modern ICTs like Internet, Intranet, Mobiles, Web Applications, and Mobile Apps by the government to improve the efficiency, effectiveness of service delivery to promote the democracy.

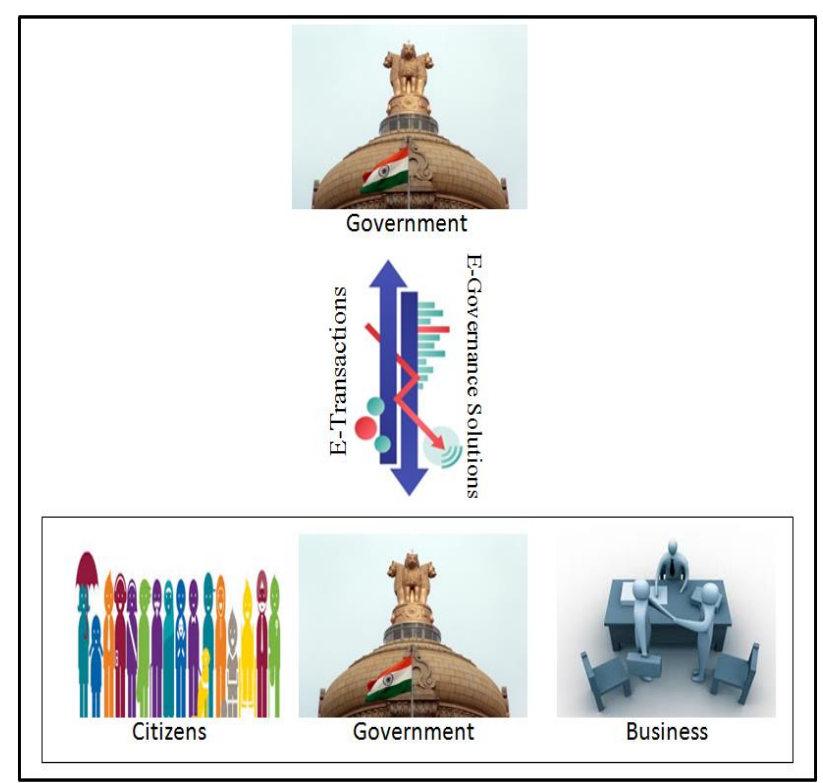

Fig.1. Conceptual model of e-Governance

The main objective of the e-governance project is to provide efficient and enhanced service delivery to the citizens. The central and state government has invested a lot on the ICT to make their functioning effective and transparent. It will also help the government departments to well organize their future investments to get maximum benefits. A citizen-centric approach enables the government to provide improved service quality, which enhances the citizen satisfaction. In this approach, the citizens are considered as customers, as in the case of the product or services based company, while providing the services to the citizen. There are several stakeholders in e-governance namely Government, Citizens, Employees, Business, Government Officers, Government Agencies, Project Managers. The e-governance initiatives are categorized as Government to Citizens (G2C), 
Government to Government $(\mathrm{G} 2 \mathrm{G})$, and Government to Business (G2B).

Section II gives concepts and evolution of egovernance in India. Section III describes the overview of Maharashtra state, DIT, State's e-Governance policy, vision and major initiatives in the state. Section IV gives briefly related work in e-governance. Section $\mathrm{V}$ gives brief challenges in e-Governance. Section VI gives concluding remark.

\section{E-GOVERNANCE IN INDIA}

The concept of e-governance in India owes its origin during the seventies with an in-house development of applications for government organizations like planning, economic monitoring, defense and the deployment of IT to manage data and intensive functions related to elections, census, tax administration etc. In the eighties, the efforts of the National Informatics Centre (NIC) to connect all district headquarters through the VSAT. In India, it was a very significant development. However, these efforts were mostly government centric for the automation of internal government functions. In the late eighties, a few computerized initiatives in the government departments started making an impact on citizen services. The most important among these initiatives was the computerization of the Indian Railways passenger reservation system. During this period, e-governance received a major thrust with the launch of NICNET in 1987 , followed by the launch of DISNIC with objective computerization of all the district offices. During the nineties, most of the central and state level government departments initiated ICT projects for improving citizen services. During the latter half of this decade, some government departments tried to use the World Wide Web for providing information to the citizens. During this period, some states achieved remarkable successes in egovernance initiatives to improve delivery of services to the citizens. During the early years of the last decade, this trend continued by several states across the implementing citizen centric e-governance initiatives. However, these initiatives were fragmented and unreachable to the taluka and village levels due to lack of enough and integrated ICT infrastructure, connectivity, backend computerization, sufficient capacity at all levels of government to efficiently deploy ICT for improving the quality of governance.

To address all these deficiencies, the Department of Electronics and Information Technology, Government of India approved the National e-Governance Plan (NeGP) in 2006 .

\section{A. National e-Governance Plan (NeGP)}

The Government of India approved the National eGovernance Plan on $18^{\text {th }}$ May, 2006 with a vision statement "Make all Government services accessible to the common man in his locality, through common service delivery outlets, and ensure efficiency, transparency, and reliability of such services at affordable costs to realise the basic needs of the common man" [4]. NeGP lays emphasis on developing the proper governance and institutional framework within India, establish the ICT infrastructure and implement a various Mission Mode Projects (MMPs) at the state, central and integrated levels. NEGP's aim and motto is "Ek Kadam Aapki Oar, Ek Kadam Apke Liye” - Public services closer home. NeGP consisting originally of 27 MMPs and 8 Components, during July 2011, 4 new MMPs were added.

Next phase of NeGP is NeGP 2.0 (e-Kranti). The aim of NeGP 2.0 is to bring transformation in e-governance in India to dramatically improve its outcomes. The basic principle of NeGP 2.0 is to focus on transformation in the quality and quantity of service delivery, integration of services, use of mobile and cloud platform, Big Data Analytics, effective use of social media.

Fig. 2 shows the month wise number of e-Transactions of CSC, PDS and LR of the MMPs during the January to June 2015 [5].

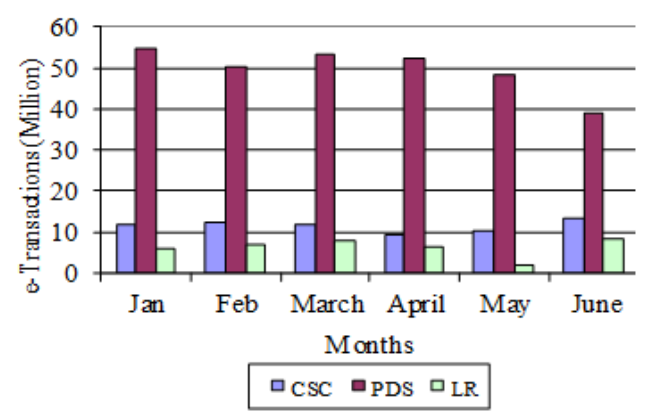

Fig.2. No. of e-Transactions during January 2015 to June 2015

\section{E-GOVERNANCE IN MAHARASHTRA}

\section{A. Maharashtra state at a glance}

Maharashtra is the second most populous state in the India with 112.4 million population and the literacy rate is $82.34 \%$. $45.2 \%$ share of urban population in the state [6]. The Maharashtra has 6 divisions are further divided into 36 districts, 109 Sub-Divisions, 357 talukas. There are 534 Towns and 43665 total villages in Maharashtra [7]. Marathi is the official language of Maharashtra and is written in Devanagari script. Apart, also speaks Hindi, Konkani, Gujarati, and English languages.

\section{B. Directorate of Information Technology (DIT)}

The Directorate of Information Technology, Government of Maharashtra (GoM), was established in 1998 to achieve the goals of to develop ICT and eGovernance in the state. DIT is liable for designing the policy framework, supervising the state government's egovernance projects and protect inter-departmental coordination to achieve the vision of the GoM. The DIT is also responsible for

- Statewide creation of core infrastructure like State Data Centre (SDC), State Wide Area Network (SWAN), Common Service Centres (CSC) 
- E-enablement of services

- Implementation of internal and common applications for improving efficiency in Government functioning

- Technical advisory and people support among other activities.

Maharashtra is the pioneer state in the adoption of technology that supplements improvement in transparency and accountability of the Government. The efforts of the state have been focused on cutting edge technology initiatives with the overall administration, intention to take the government to the citizens' doorsteps as an usher in a digitally inclusive society [8].

\section{Maharashtra state e-Governance policy}

Maharashtra is the first state in the country to have a dedicated e-Governance policy published on 23 September, 2011 in local language i.e. Marathi and also in English language. Maharashtra e-Governance Policy plan and timelines was issued on 10 April, 2012. The eGovernance policy objective is to ensure standardized and seamless implementation of e-governance projects across state. Policy issued several guidelines about use of UID, use of Marathi language in e-Governance implementation, utilization of multiple service delivery channels to provide citizens services at their doorsteps, various citizen services shall be made available online through the state portal to be developed in-line with the national portal and through other channels like CSC (Maha E-Seva Kendra), SETU, Common Facilitation Centre (CFC)etc., State Service Delivery Gateway (SSDG) shall act as hub for all the interaction between service seekers and providers, capacity building, joint venture, collaboration and partnership with private companies [9].

\section{Vision of e-Governance of Maharashtra}

The Maharashtra state's vision is "Transforming Governance and Enriching lives through Information and Communication Technology".

The policy provides seamless guidance to all the departments and administrative structure as a whole to prepare and take up meaningful citizen centric egovernance initiatives. To achieve the e-governance goals, GoM has lay down six pillars (shown in Fig.3) which will facilitate state departments to use e-governance as a tool to become more proactive and responsive to the citizens [8].

The state government has adopted e-governance to reach out in a more effective manner to the people and the conventional functioning is being modernized through the exhaustive Business Process Reengineering (BPR) and electronic service delivery. The useless steps in the workflow are being thrown away with to ensure faster decision making and, service delivery complimented by back office and workflow automation.

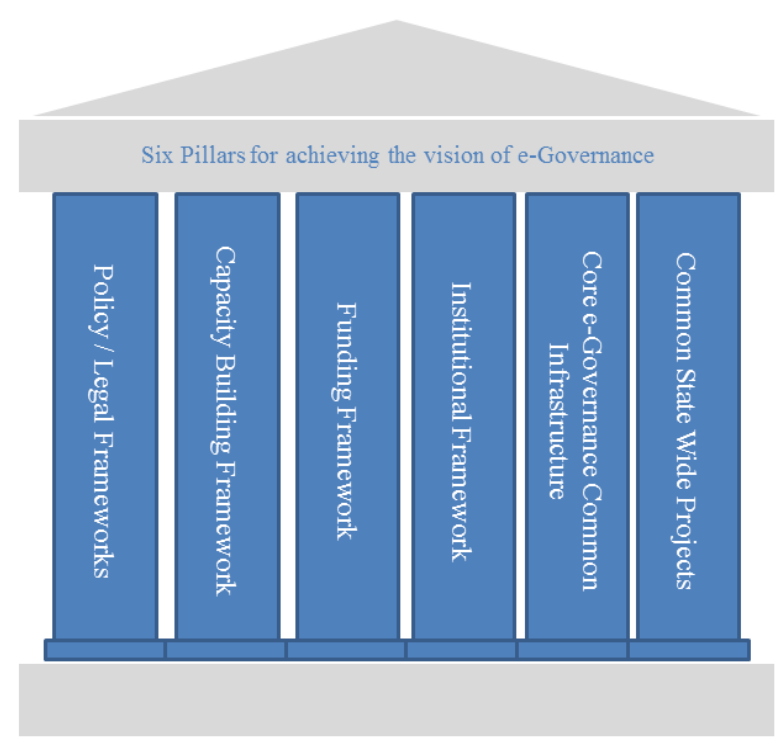

Fig.3. Six Pillars for achieving the Vision of e-Governance

\section{E. Major e-Governance initiatives in Maharashtra}

Maharashtra state government initiated various egovernance projects in the state (shown in Table 1). Most of these projects are governed by the Collector Office of each district. District Collectorate is responsible for implementing central and state level e-governance projects through their subsidiary offices or officers like Deputy Collector Office, Tahsil Office, Talathi Office. In this study, we are concentrating on three main citizen centric initiatives i.e. Common Service Centre (CSC)/SETU, Public Distribution System (PDS) and Land Record (LR).

Table 1. Major e-Governance projects in Maharashtra state

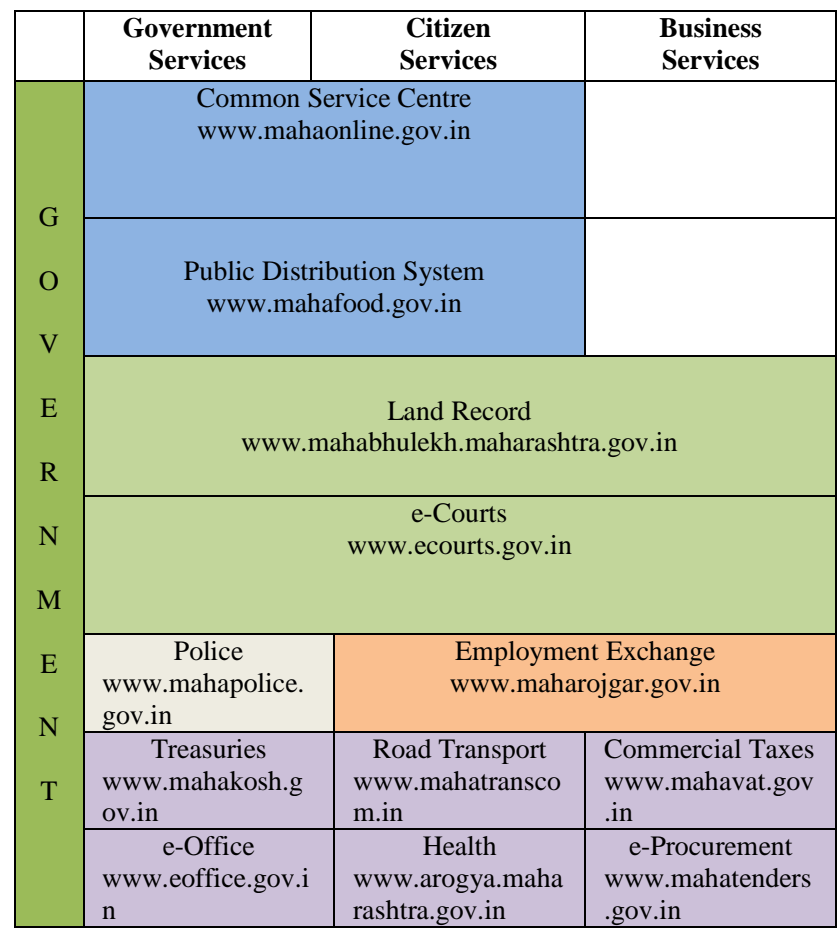




\section{RELATED WORKS}

Past e-governance implementation efforts have focused mainly on internal efficiency, effectiveness and government centric. Currently, e-governance initiatives are more focused on the electronic delivery of service to the stakeholders and citizen centric. The present review includes all studies related to e-governance initiatives like Common Service Centre, Public Distribution System, and Land Record Management System. This review search specially selected articles published in journals, conference proceedings, books, technical articles, research articles, the government published reports, government resolutions, policy papers and $\mathrm{Ph} . \mathrm{D}$. thesis submitted in various universities.

\section{A. Common Service Centre (CSC)}

Common Service Centres (Maha e-Seva Kendra) is one of e-governance initiative for delivering the common service to the common people. These services are provided by CSCs, SETU, Sangram Kendras and Citizen Facilitation Centres (CFC) of Municipal Corporations in Maharashtra.

Swati Sardesai (2008), Ph.D. thesis [10], the research is based substantially on Citizen Centric E-Governance project Citizens Facilitation Centers of Kalyan Dombivali Municipal Corporation. According to this research finding, e-governance project gets delayed due to insufficient fund, transfer of project leader or head of the department. Municipal Corporation is the local autonomous body who can implement their e-governance projects in corporation jurisdiction. Means this project is limited to the Municipal Corporation area only where the literacy rate is more than the rural area.

Another researcher Rakesh Patil (2010), [11] in his study focuses the facilities available, progress, development and strategy for implementation of egovernance in government organizations in Nashik district. The researcher has observed the e-governance initiatives influence on the citizens of Nashik District. Citizens Service Centres like SETU helped to promote the transparency and accountability and provide a friendly interface to citizens. The researcher has identified some factors which are affecting the egovernance projects. By considering these problems researcher, has developed e-governance model for implementing and successful execution of e-governance. The researcher thought that if these factors are considered during the implementation phase and execution of the project, it is sure that e-governance in Nashik District will be more efficient and effective. In this research, the scope of research is government organizations which are located in Nashik district and there is a lack of citizen's involvement.

Manisha Kumbhar (2012), in her Ph.D. thesis [12], the research is based on the ICT and e-governance initiatives in Pune Municipal Corporation. Her research reveals that majority young citizens are using e-governance services and awareness is dependent on citizen's age group. The knowledge of Information Technology as well as its literacy is one of the reasons for awareness among young citizens.

Sushil Kumar (2012), in his Ph.D. thesis [13], the study mainly focused on measuring the levels of satisfaction amongst citizens and government agencies toward egovernance initiatives particularly Single User-friendly Window Disposal Helpline for Applicants (SUWIDHA) in the state of Punjab. The researcher agreed that egovernance initiatives serve with better efficiency, minimize the costs and has bright future with more satisfied citizens and SUWIDHA employees.

Amirhossein Alibaygi, Mehdi Karamidehkordi and Esmail Karamidehkordi, [14] in their research paper, assess the effectiveness of rural ICT centres for developing e-governance in the rural section of the Kermanshah township in Iran. Lay the groundwork for the rural ICT centres has been one of the foremost national policies of Iran for the purpose of providing ICT services to rural section. The researcher concluded that the ICT centres less impact on household income changes and access to information with respect to agriculture input and output prices.

Sanjay Jaju, Anoop Singh (2013), the authors explained [15], MeeSeva is the integrated service delivery model of Andhra Pradesh government. This project was launched in Chittoor district on the pilot basis Through more than 7000 kiosks, the project providing user-friendly, faster, and transparent to various G2C services to the citizens. The project was initiated with a seed investment of Rs. 9 crore; the user fee model and 2.6 crore transactions in a day, rising up to 2 lakh transactions in a day, yearly savings to citizens could be whopping Rs. 6000 crore. More than 99\% of the transactions have been delivered within the promised citizen's charter time limits.

Sanjay Tejasvee (2013), [16] presented the Effective Deliverance of Information and Services to the Citizens (E-DISC) architecture for the better sustain for inter and intra-departmental working flow, and deliver good quality and on time provision of e-services to the citizens with flexibility and integrating new applications and services. This conceptual solution model is the initiate to be moderately comprehensive describe important features that need to be handled in e-governance projects. The implementation of e-governance projects in Rajasthan and its divisions can be made very successful and effective by accepting this E-DISC architecture to work with some important consideration in dealing.

There must be a single window system where all the citizens related documents, affidavits, certificate can issue to the common people within a time. The government should prepare the assessment framework for assessing the e-government projects time to time. Assessment framework should be in terms of the cost for availing the service, overall assessment, quality of service and the quality of governance. Feedback system also plays an important role in impact assessment and sustaining of the e-governance projects in the state. Feedback should take from the end user of the project like citizens, stakeholders, managers etc. Based on the 
assessment and feedbacks from the projects, the government should take the corrective actions.

\section{B. Public Distribution System (PDS)}

India's Public Distribution System (sarvajanik vitaran pranali) is the largest distribution system in the world. This system distributes subsidized food grains and nonfoods item to the beneficiaries. Several reports are published on PDS by the Government of India (GOI). Ministry of Finance, GoI formed Task Force published a report recommended suggestions along with the IT enabled reforms in order to attempt a comprehension solution for deficiency in PDS. Also, Task Force recommended the set up of National Information Utility called the PDS Network (PDSN) which operates as a technology back office and central system for Ministry of Consumer Affairs and Public Distribution, Ministry of Petroleum and Natural Gas, and state government [17].

M. Vinayak Rao, A. N. Siddiqui and Musharraf Sultan (2008), [18] authors explains the e-governance project implemented with the vision. Initially in this project, twotier architecture was implemented. But the system needed operators for data transmission, consolidation and website replication. To overcome these problems, the process is re-engineered using multi-tier architecture (Web-enabled) with Microsoft .NET Framework. NIC developed this project. Food departments and NIC resources like IDC, NICNET and district centres resources have been used. Once in a week senior officers of the Food Department monitor the system. There must be a real-time monitoring system for PDS.

B. S. Sawant, Rahul J. Jadhav (2013), [19]. This paper investigates the impact of PDS in the Indian context of social security and poverty alleviation. The researchers found that the needy people do not get food grains which are allotted based on their poverty. From above study, conclude that the researchers studied the physical distribution of the food grains through PDS in Satara district. There is no communication between distribution centre and the actual needy citizens. To overcome this, there is need of ICT based public distribution software system.

Raj Kumar (2014), [20], in his article, the author focused on Targeted Public Distribution System (TPDS). TPDS is a policy to provide food security to the socially weaker and vulnerable sections. TPDS reforms seek to address these deficiencies by empowering the beneficiary through the modern ICT and governance processes. For ensuring delivery of food grains and the non-food items to the beneficiary; problems like duplicate ration cards, non-existing beneficiaries must be removed. The government started issuing 2D barcodes ration cards for the delivery of commodities to real beneficiaries. Beneficiary's photo and biometric barcode based PDS will help to resolve the problem of monitoring, grievance redressal or control issues and improving transparency in the PDS system.

The Planning Commission had performance evaluation in 2004-05 of the TPDS found that inefficiency in the system meant currently the government spends Rs. 3.65 to deliver Rs. 1 of food while $57 \%$ of subsidized food grains and non-food items do not reach to the needy beneficiaries [21].

PDS in Maharashtra, the entire process is manual and there is no real-time record of the actual distribution, no automated system to track the total number of active ration cards in Food and Civil Supply department. Pilferage may occur at a different level in the distribution network, middlemen typically try to take advantage of this by procuring on the basis of the registered cards which may not directly correlate with the actual number of active cards. There are massive corruption and pilferages in existing PDS. To overcome these issues, use a technology which monitors real-time data and improves the efficiency of the supply chain like GPS, linkage of UID with the PDS, use of smart cards for the beneficiary, biometric identification of beneficiary. There must be a Public Private Partnership (PPP) to develop the system. The government also needs to check the efficiency and effectiveness of the system from the private agencies.

\section{Land Record (LR)}

The land revenue is the main source of revenue for all state governments. There are several land record management systems which are implemented in India. The government of Karnataka and NIC Karnataka jointly implemented Bhoomi Project in the Karnataka state and it is the first e-governance project successfully implemented. Bhoomi has become the model for replication in many other states in India. Bhoomi Kiosks are set up in each taluka to issue land related documents to citizens on demand. It requires biometric authentication to ensure foolproof system. Public Affairs Council, Bangalore conducted an evaluation of Bhoomi project in July 2002, showed significance impact on efficiency in delivery and corruption. 66\% users were able to utilize the Bhoomi Kiosk without any help, while in case of manual system it is $25 \%$. $74 \%$ users indicated that Bhoomi Kiosk provides error-free documents, which is $63 \%$ in case of manual system [22].

Somayajulu Garimella, Srinivas Kolluru [23] in their research article on Lokmitra e-Governance project implemented in Himachal Pradesh stated that $97 \%$ of the respondents were literate in the state. More than $80 \%$ of the respondents had access to computers and $70 \%$ of them were using the internet for accessing various services. Approximately $70 \%$ of the users indicated that they are aware of the project and the services offered.

Swati Sardesai [10] one of the e-governance researcher stated in her study that $7 / 12$ extracts of land are mainly required by farmers i.e. $94.8 \%$. All age group citizens are making immense use of computerized land records system, but age group around 40 years are availing maximum services. Citizens require $7 / 12$ extract is average 5 times in a year.

Moreover studying success stories of land record and revenue governance from India, K.M. Baharul Islam [24] argued that data entry work was done offline by private agencies. Due to poor knowledge and work culture, the process was very slow and error prone. Data moves 
through NICNET at different levels from the district level to state level and then to centre so that there is need of networking scheme.

Vivek Gupta, in his article [25], Indian Institute of Management Ahmadabad, NIC and District Collectorate of Durgapur collectively implemented first pilot project of Land Record Computerization of Durgapur district in India in 1980. It took fourteen years to complete first stage. Roles and responsibilities were not defined among the staff. Therefore, there was confusion among the staff. Hence, the pilot project could not take as standard to be deploy in another district. Before implementing the project, define the roles and responsibilities clearly for the staff regarding the project.

Several researchers suggested the need for awareness of the initiatives among the citizens and essential training for the stakeholders of the projects. The government should take care while selecting the private agency for implementation of e-governance projects without any political influence. Also, the government should reform the process using ICT and ICT tools. Information and database should be in digital form not in manual. The information flow among all the government departments and private agencies should be automated. Periodically government must undertake outcome based assessment of e-governance initiatives. Also need to assessment of ereadiness of states and union territories.

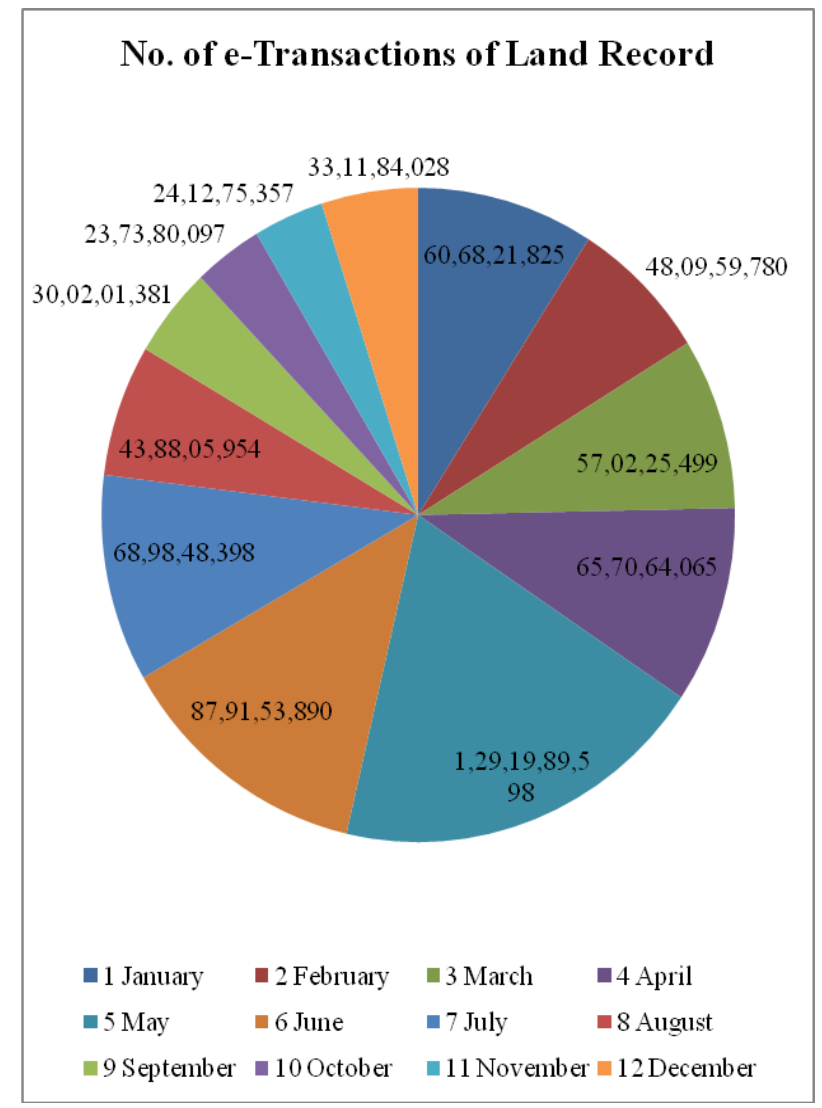

Fig.4. No. of e-Transactions of Land Record from January to December 2015 (Source: E-Taal Webiste)

\section{Challenges In E-GovernanCE}

\section{A. Funding}

The funds are the major problem of e-governance projects. The funds are allocated initially but afterwards, funds for the maintenance or extension of the project are not sufficient.

\section{B. Infrastructure}

For any projects, the infrastructure is necessary for smooth delivery of the services. It includes the high performance servers, network to each and every village in the state, high speed internet connection etc.

\section{Key Person}

In e-governance projects, there is a huge lack of technical or trained persons. Key Person who understands project management and has sufficient skill getting transferred and that is quite frequent. Due to it, so many ongoing projects are suffering, hence are incomplete.

\section{Politics}

In the state, political willpower is necessary to implement the e-governance projects. A strong and visionary political leadership is essential.

\section{E. Integration of Services}

Most of the e-governance initiatives are being offered by the Central or State government. At many occasions or on many projects, there is a lack of coordination between these two governments. As a result, new projects couldn't be started or ongoing projects couldn't become successful.

\section{$F$. Language}

The local language is mandatory for official communication in the India. Therefore, the delivery of egovernance services in local language is necessary.

\section{G. Resistance to Change}

Every organization is against change. The employees are worries of their jobs. The employees or official who are directly or indirectly involved in e-governance initiatives is opposing for change in the existing system.

\section{H. Capacity Building}

The government must put efforts to enhance the capacities and empowering stakeholders capacity at all levels within the government for the effective implementation of any e-governance program. There is also need to change management training to the staff, officials who are directly or indirectly involved in egovernance initiatives.

\section{Measuring the success of initiatives}

There is a great need to develop and adopt the measurement of success of e-governance to deliver smoothly to the citizens. 


\section{CONCLUSIONS}

Electronic service delivery is changing from government centric to citizen centric. The citizens are the most important in citizen centric government service delivery. To develop citizen centric e-governance initiatives, there is a need of strong vision and political willpower. Cloud platform avoids duplication of infrastructure and help in interdepartmental coordination for service delivery. E-Governance policies are must be strictly implemented. Various researchers point out a lack of funds i.e. the e-governance projects are able to sustain if projects are allocated on time and are adequate. Although Maharashtra is ahead in public delivery of services in India but there are some problems at ground level. There was a lack of involvement of the real implementers of the e-governance projects i.e. district administration and revenue department officers in the projects. Objectives are defined citizens point of view i.e. citizen centric objectives. It is observed in e-governance project implementation is that key person is transferred while implementation phase. Most of the e-governance initiative's objectives, goals, vision are same but the way of delivery is different. To overcome these problems, there is a need for a common vision, objectives, goals and common solution architecture for all states. There must be unanimity in service delivery in all states in India.

\section{ACKNOWLEDGMENT}

We express our sincere thanks to all authors, whose articles published in the area of e-governance in various conference proceedings and journals. Our special thanks to Prof. Subhash Bhatnagar, Indian Institute of Management, Ahmedabad for their work on e-governance published in various conferences and journals.

\section{REFERENCES}

[1] United Nations Educational, Scientific and Cultural Organization, [Online]. Available: http://portal.unesco.org/ci/en/ev.phpURL_ID=3038\&URL_DO=DO_TOPIC\&URL_SECTIO $\mathrm{N}=201 . \mathrm{html}$

[2] A.P.J. Abdul Kalam. "A Vision of Citizen-Centric EGovernance for India." In The State, IT and Development, R. K. Bagga, Kenneth Keniston, and Rohit Raj Mathur, Eds. Sage New Delhi, 2005, pp 1-7.

[3] Michiel Backus, "E-Governance and Developing Countries Introduction and examples", International Institute for Communication and Development, Research Report, No.3 April 2001

[4] Department of Electronics and Information Technology, Government of India. National e-Governance Plan, [Online]. Available: http://deity.gov.in/content/national-egovernance-plan

[5] Department of Electronics and IT, Ministry of Communication and IT, Government of India. Electronic Transaction Aggregation and Analysis Layer (E-Taal), [Online]. Available: http://etaal.gov.in

[6] Government of India. Census of India 2011. [Online]. Available: http://www.censusindia.gov.in
[7] Government of Maharashtra, Official Website, District, [Online]. https://www.maharashtra.gov.in/1128/Districts

[8] Directorate of Information Technology, "State of eGovernance in Maharashtra 2014", Government of Maharashtra, Mantralaya, Mumbai, 2014.

[9] Directorate of Information Technology, Government of Maharashtra, India. (2011, September 23). E-Governance Policy of Maharashtra-2011, [Online]. Available: https://www.maharashtra.gov.in/PDF/e_governance_polic y.pdf

[10] Swati Sardesai "Study of Citizen Centric e-governance, Projects in Maharashtra", Ph. D. Thesis. University of Pune, Pune India. 2008.

[11] Rakesh Patil, "A Study of Progress, Development and Strategy of Government Organizations Regarding eGovernance In Maharashtra State with special reference to Nashik District", Ph.D. Thesis, University of Pune, Pune, India. 2010.

[12] Manisha Kumbhar "A Critical Study of Implication of egovernance Services for effective communication with special reference to Citizens in Pune City", Ph.D. Thesis, Tilak Maharashtra Vidyapeeth, Pune, India. 2012

[13] Sushil Kumar, "Design of Framework to Improve Effectiveness of E-Governance in the state of Punjab", Ph.D. Thesis, Punjabi University, Patiala, India. 2012.

[14] Amirhossein Alibaygi, Mehdi Karamidehkordi and Esmail Karamidehkordi, "Effectiveness of Rural ICT Centers: A perspective from west of Iran", Procedia Computer Science Vol 3, 2011, pp 1184-1188.

[15] Sanjay Jaju, Anoop Singh. "MeeSeva, Andhra Pradesh", in Compendium of Selected eGovernance Initiatives in India2013, Harish P. Iyer, K. S. Vijaya Sekhar, Ayaluri Sridevi, and Piyush Gupta, Eds. Virtual Reality, 2013.

[16] Sanjay Tejasvee, "Implementation of Integrated EGovernance in Bikaner Division", Ph.D. Thesis, Suresh Gyan Vihar University, Jaipur, India. 2013

[17] Ministry of Finance, Government of India. (October, 2011). "Report of the Task Force on an IT Strategy for $P D S$ and an implementable solution for the direct transfer of subsidy for Food and Kerosene" [Online]. Available: http://finmin.nic.in/reports/it_strategy_pds.pdf

[18] M. Vinayak Rao, A. N. Siddiqui and Musharraf Sultan, "ePublic Distribution Monitoring System-e-PDMS", in Compendium of eGovernance Initiatives in India, Piyush Gupta, R.K. Bagga, Eds. University Press, 2012

[19] B. S. Sawant, R. J. Jadhav, "Public Distribution System of Essential Commodities as a Social Security (A Study of Satara District Maharashtra)", International Journal of Management \& Business studies, Vol. 3, Issue 1, Jan March 2013, Pp. 31-33.

[20] Raj Kumar, "GUJARAT Model of TPDS Reforms: Biometric Based Barcoded Coupon System of PDS delivery", [Online]. Available: http://www.fcsca.gujarat.gov.in/Images/pdf/tpdsinforation.pdf

[21] Program Evaluation Organization, Planning Commission, Government of India. (March, 2015). "Performance Evaluation of Targeted Public Distribution System (TPDS)" [Online]. Available: http://planningcommission.nic.in/reports/peoreport/peo/pe o_tpds.pdf

[22] Rajeev Chawla, "Bhoomi*: Online Delivery of Record of Rights, Tenancy and Crops to farmers in Karnataka, India". National Institute for Smart Government, New Delhi. 2004 pp 76-99. 
[23] Garimella, Somayajulu and Kolluru, Srinivas, WebEnabled Government-Citizen Interface in India - The Case of Lokmitra (April 26, 2011). Journal of E-Governance, Vol. 34, No. 2, pp. 95-103, 2011. Available: http://ssrn.com/abstract $=2046438$

[24] K. M. Baharul Islam, "Information Age Government: Success Stories of Online Land Records \& Revenue Governance from India". Executive Summary, Third Meeting of the Committee on Development Information (CODI), Economic Commission for Africa, United Nations Economic and Social Council, Ethiopia, 10-17 May 2003.

[25] Vivek Gupta, "E-governance: Lessons from District Computerization", IFIP Newsletter, International Federation for Information Processing, Vol. 12, No. 1, April 2002.
Graduate level. His research activities include e-Governance, ICT.

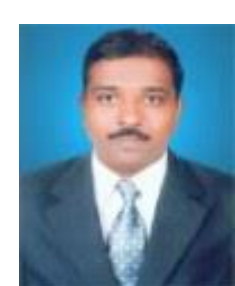

Dr. Rajendra D. Kumbhar, Assistant Professor in System Management Department of Karmveer Bhaurao Patil Institute of Management Studies and Research, Satara, Maharashtra, India. He is pursued MCA, Ph.D. Computer Application from Shivaji University, Kolhapur. He has 15 years of Teaching experience in System Management for UG and PG. His research area is e-Governance, ERP. He has published 22 research articles in refereed journal.

\section{Authors' Profiles}

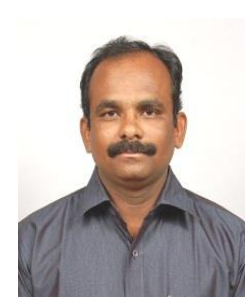

Laxman L. Kumarwad, Assistant Professor in Master of Computer Application Department at Government College of Engineering, Karad, Maharashtra in India. He is pursued MCA degree from University of Pune, India and now pursuing Ph.D. in Computer Application from Shivaji University, Kolhapur, India. He has 7 years of teaching experience at Post

How to cite this paper: Laxman L. Kumarwad, Rajendra D. Kumbhar,"E-Governance Initiatives in Maharashtra (India): Problems and Challenges", International Journal of Information Engineering and Electronic Business(IJIEEB), Vol.8, No.5, pp.18-25, 2016. DOI: 10.5815/ijieeb.2016.05.03 